\title{
Conspecific hyperparasitism in the Hyalomma excavatum tick and considerations on the biological and epidemiological implications of this phenomenon
}

\author{
Alicja Buczek ${ }^{1, A-F}$, Katarzyna Bartosik' ${ }^{1, B-F} \oplus$, Alicja Magdalena Buczek ${ }^{1, D, F}$, Weronika Buczek ${ }^{1, D, F}$, \\ Michał Stanko ${ }^{2,3, D-F \circledast ~}$ \\ ${ }^{1}$ Chair and Department of Biology and Parasitology, Medical University, Lublin, Poland \\ ${ }^{2}$ Institute of Parasitology, Slovak Academy of Sciences, Slovak Republic \\ ${ }^{3}$ Institute of Zoology, Slovak Academy of Sciences, Slovak Republic \\ A - Research concept and design, B - Collection and/or assembly of data, C - Data analysis and interpretation, \\ $D$ - Writing the article, E - Critical revision of the article, F - Final approval of article
}

Buczek A, Bartosik K, Buczek AM, Buczek W, Stanko M. Conspecific hyperparasitism in the Hyalomma excavatum tick and considerations on the biological and epidemiological implications of this phenomenon. Ann Agric Environ Med. 2019; 26(4): 548-554. doi: 10.26444/aaem/110128

\begin{abstract}
Objective. This study presents for the first time a case of Hyalomma excavatum hyperparasitism and an analysis of this phenomenon in terms of its potential role in the biology of ticks and epidemiology of tick-borne diseases.

Materials and method. Two partially engorged $H$. excavatum females, one fully engorged female, and 5 males were collected from a naïve rabbit and placed together in a rearing chamber at a temperature of $25^{\circ} \mathrm{C}$ and $75 \%$ humidity.

Results. 3-4 days after tick detachment from the host's skin, one partially engorged $H$. excavatum female was observed attached to the idiosoma of the fully engorged conspecific female.

Conclusions. This study and observations of other authors confirm that partially engorged ixodid ticks can re-infest the host, and even co-feeding fully engorged ticks in order to collect the blood meal that is indispensable for important physiological processes. However, inefficient feeding of a partially engorged female on another conspecific female may reduce its reproductive performance and disturb the development of eggs and larvae. It seems that parasitism of a tick on another conspecific specimen, when at least one of them is infected by a microorganism, may be a yet poorly explored route of transmission of pathogens or symbionts between the ticks. Initiation of feeding by a hungry or partially engorged tick on a fully engorged specimen is an attempt to obtain food in the drastic conditions of the absence of a target host. Tick hyperparasitism with concurrent pathogen transmission can contribute to the genospecific diversity of pathogens in vectors and hosts.
\end{abstract}

\section{Key words}

ticks, Hyalomma excavatum, hyperparasitism, transmission of pathogens, tick feeding

\section{INTRODUCTION}

Ticks have a remarkable ability to adapt to various environments in the globally changing geoclimatic conditions, which contributes to the expansion of their distribution range. The increasing occurrence of ticks is accompanied by a growing risk to human and animal health posed by tick-borne diseases [1] and, hence, greater economic losses and costs $[2,3,4]$. Therefore, investigation of the biology of ticks and transmission routes of tick-borne pathogens is gaining importance.

Ticks are blood-ingesting parasites of terrestrial vertebrates, including humans. Ingestion of a blood meal by consecutive developmental stages is a prerequisite for tick survival and further development. The major mode of blood collection by ticks involves questing for a host, followed by successful feeding. Ticks are distinguished from other blood-ingesting arthropods by a variety of bioactive compounds secreted

Address for correspondence: Alicja Buczek Medical University, Chair and Department of Biology and Parasitology, Poland

E-mail: alicja.buczek@umlub.pl

Received: 11.05.2019; accepted: 19.06.2019; first published: 06.08.2019 with saliva during feeding, which facilitate ingestion of a qualitatively and quantitatively sufficient meal during short(Argasidae nymphs and adults) and long-term (Ixodidae) feeding [5], and ensure effective pathogen transmission [6].

Besides infesting their vertebrate hosts in order to collect blood, hungry ticks can also attack engorged conspecific or interspecific specimens. This phenomenon, called hyperparasitism, was described in ticks already at the end of the $19^{\text {th }}$ century by Barber [7], who found an Amblyomma variegatum male (identified by the author as Hyalomma venustrum) parasitizing a female from the same species. In the family Argasidae, hyperparasitism was noted mainly in representatives of the genus Ornithodoros. In turn, in the family Ixodidae, the phenomenon was reported from several species of the genus Ixodes (prostriata ticks), as well as genera Amblyomma, Aponomma, Rhipicephalus (Boophilus), Dermacentor, Hyalomma, and Rhipicephalus (metastriata ticks) (Tab. 1).

Since many viruses, bacteria, protozoa, and even some microfilaria, are transmitted with tick saliva secreted during the feeding process $[1,3,8]$, it seems possible that parasitism of one tick on another may play a role in the spread of pathogens in the environment. The fact that conspecific 
Table 1. Reports about cases of conspecific and interspecific hyperparasitism in ticks (Ixodida)

\begin{tabular}{|c|c|c|c|c|}
\hline $\begin{array}{l}\text { Hyperparasitic specimen and } \\
\text { degree of engorgement }\end{array}$ & $\begin{array}{l}\text { Host specimen and degree of } \\
\text { engorgement }\end{array}$ & Distribution of tick species/habitat & Main animal hosts & References \\
\hline \multicolumn{5}{|l|}{ Conspecific hyperparasitism } \\
\hline \multicolumn{5}{|l|}{ Argasidae ticks } \\
\hline $\begin{array}{l}\text { Ornithodoros turicata } \\
\text { unengorged female }\end{array}$ & $\begin{array}{l}\text { Ornithodoros turicata² fully } \\
\text { engorged female }\end{array}$ & $\begin{array}{l}\text { Southern part of North America, from } \\
\text { Kansas south to central Mexico, with a } \\
\text { disjunct population in Florida/ caves and } \\
\text { ground squirrel or prairie dog burrows }\end{array}$ & $\begin{array}{l}\text { Mammals, e.g. rodents that live in } \\
\text { burrows, domestic pigs, cattle and } \\
\text { other livestock; birds, e.g. owls; } \\
\text { reptiles, e.g. snakes; tortoises (A, I); }\end{array}$ & $\begin{array}{l}\text { Wood } \\
\text { according to } \\
{[28]}\end{array}$ \\
\hline $\begin{array}{l}\text { Ornithodoros turicata }{ }^{2} \text { (former } \\
\text { Ornithodoros turicata americanus) }\end{array}$ & $\begin{array}{l}\text { Ornithodoros turicata }{ }^{2} \\
\text { former Ornithodoros turicata } \\
\text { americanus) }\end{array}$ & & & \\
\hline $\begin{array}{l}\text { Ornithodoros turicata' starved } \\
\text { female }\end{array}$ & $\begin{array}{l}\text { Ornithodoros turicata }{ }^{1} \text { fully } \\
\text { engorged male }\end{array}$ & & & $\begin{array}{l}\text { Francis } 1938 \\
\text { according to } \\
{[28]}\end{array}$ \\
\hline $\begin{array}{l}\text { Ornithodoros turicata }{ }^{1} \text { unfed } \\
\text { fourth stage nymph }\end{array}$ & $\begin{array}{l}\text { Ornithodoros turicata engorged } \\
\text { nymph }\end{array}$ & & & $\begin{array}{l}\text { Francis } 1938 \\
\text { according to } \\
{[28]}\end{array}$ \\
\hline $\begin{array}{l}\text { Ornithodoros parkeri }{ }^{1} \\
\text { unengorged last nymphal stage }\end{array}$ & $\begin{array}{l}\text { Ornithodoros parkeri }{ }^{1} \\
\text { fully engorged last nymphal } \\
\text { stage }\end{array}$ & $\begin{array}{l}\text { Southern USA and Latin America/various } \\
\text { ecological habitats in caves and burrows } \\
\text { of hosts }\end{array}$ & $\begin{array}{l}\text { Mammals, e.g. ground squirrels and } \\
\text { prairie dogs }(A, I)\end{array}$ & {$[66]$} \\
\hline
\end{tabular}

Ornithodoros parkeri' unengorged Ornithodoros parkeri' fully

males engorged female

\begin{tabular}{|c|c|c|c|c|}
\hline $\begin{array}{l}\text { Ornithodoros erraticus }{ }^{1} \text { males and } \\
\text { nymphs that produced males }\end{array}$ & $\begin{array}{l}\text { Ornithodoros erraticus }{ }^{1} \text { females } \\
\text { and nymphs that produced } \\
\text { females }\end{array}$ & $\begin{array}{l}\text { North and East Africa, Near East, South- } \\
\text { Eastern Europe/ burrows of pig pens or } \\
\text { other habitats of hosts }\end{array}$ & $\begin{array}{l}\text { Mammals, e.g. pigs, bovine, sheep, } \\
\text { rodent, and rarely also birds }(A, I)\end{array}$ & [50] \\
\hline Ornithodoros tartakowskyi ${ }^{3}$ & Ornithodoros tartakowskyi ${ }^{3}$ & Central Asia/ burrows of various rodents & $\begin{array}{l}\text { Mammals: rodent species, } \\
\text { but primarily the great gerbil, } \\
\text { Rhombomys opimus }(A, I)\end{array}$ & [49] \\
\hline Ornithodoros tartakowskyi ${ }^{3}$ & Ornithodoros tartakowskyi ${ }^{3}$ & Central Asia/ burrows of various rodents & Reptiles (A, I) & [8] \\
\hline $\begin{array}{l}\text { Ornithodoros (Alectorobius) } \\
\text { puertoricensis }^{2}\end{array}$ & $\begin{array}{l}\text { Ornithodoros (Alectorobius) } \\
\text { puertoricensis }{ }^{2}\end{array}$ & & $\begin{array}{l}\text { Small mammals, e.g. rats, and also } \\
\text { amphibians, reptiles }\end{array}$ & [68] \\
\hline
\end{tabular}

$(\mathrm{A}, \mathrm{l})$

Ixodidae ticks (Prostriata ticks)

\begin{tabular}{llll}
\hline Ixodes holocyclus 1 males & $\begin{array}{l}\text { Ixodes holocyclus engorged } \\
\text { females }\end{array}$ & $\begin{array}{l}\text { Australia, mainly along coastal eastern } \\
\text { area / areas of high rainfall, e.g. wet }\end{array}$ & $\begin{array}{l}\text { Small mammals, birds; sometimes } \\
\text { reptiles (I); mammals, mainly } \\
\text { sclerophyll forest and temperate rainforest }\end{array}$ \\
& carnivores and ungulates (A, I)
\end{tabular}

Ixodes holocyclus ${ }^{1}$

Ixodes holocyclus ${ }^{1}$ female

sclerophyll forest and temperate rainforest carnivores and ur

Ixodes pilosus ${ }^{3}$ males $\quad$ Ixodes pilosus ${ }^{3}$ females Africa - tropical part/bush, humid habitats

\begin{tabular}{lll} 
& Africa - tropical part/bush, humid habitats \\
\hline Ixodes trianguliceps ${ }^{3}$ males & Ixodes trianguliceps ${ }^{3}$ female & $\begin{array}{l}\text { Euroasia/forests, hedgerows and heaths, } \\
\text { open areas }\end{array}$
\end{tabular}

unam

Mammals, mainly carnivores and

gulates $(A, I)$

Ixodes (Afrixodes) moreli males $\quad$ Ixodes (Afrixodes) moreli female

Ixodes persulcatus ${ }^{1} \quad$ Ixodes persulcatus ${ }^{1}$

males

females open areas

rodents

Ixodes angustus ${ }^{2}$ male

Ixodes angustus ${ }^{2}$ engorged female
Euroasia, from Nord-Eastern Europe through Central and Northern Asia to the Peoples Republic of China, Taiwan and North Korea, and northern Japan/ usually mixed deciduous-coniferous forests, taiga Holarctic region, mainly northern latitudes or mountain regions of southern latitudes in North America, also Japan, and Eastern Russia/ cool, moist habitats, including forests (particularly coniferous tracts), and along the shores of rivers. Rarely found outside the nest of its host.

[9]

Mammals, mainly ungulates

Small and medium-sized mammals, birds, and reptiles (I);

Medium-sized and large mammals, mainly wild and domestic ungulates, hares and dogs (A)

Small mammals, mainly rodents (voles, mice and the red squirrels) and shrews $(\mathrm{I}, \mathrm{A})$. Rarely feeds on humans or domestic

animals.

West-Central and Central Africa, Asia (Southern Arabia and several islands in the Indian Ocean); several islands in the ntic Ocean and Caribbean/ Savannah

Ixodidae ticks (Metastriata ticks)

Amblyomma variegatum' male [formerly Hyalomma venustrum]

Amblyomma variegatum engorged female [formerly Hyalomma venustrum]

Rhipicephalus (Boophilus) annulatus $^{3}$ (sex is unknown) annulatus ${ }^{3}$ unengorged female [formerly Boophilus annulatus] [former Boophilus annulatus]
Africa, America, Asia and Australia, tropical and subtropical regions/ areas with canopied mesquite and mixed brush vegetation
Small mammals, ground-feeding

birds, and reptiles (I); livestock, camels, antelope, and other wildlife ungulates $(A)$

Mammals, mainly undulates (cattle, [71] buffalo, bison and cervids, e.g. deer, antelopes, etc.)

[32]




\begin{tabular}{|c|c|c|c|c|}
\hline $\begin{array}{l}\text { Hyperparasitic specimen and } \\
\text { degree of engorgement }\end{array}$ & $\begin{array}{l}\text { Host specimen and degree of } \\
\text { engorgement }\end{array}$ & Distribution of tick species/habitat & Main animal hosts & References \\
\hline $\begin{array}{l}\text { Rhipicephalus (Boophilus) } \\
\text { annulatus }{ }^{3} \text { unengorged male } \\
\text { [formerly Boophilus annulatus } \\
\text { (Margaropus } \\
\text { annulatus)] }\end{array}$ & $\begin{array}{l}\text { Rhipicephalus (Boophilus) } \\
\text { annulatus }^{3} \text { engorged female } \\
\text { [formerly Boophilus annulatus } \\
\text { (Margaropus } \\
\text { annulatus)] }\end{array}$ & & & $\begin{array}{l}\text { Hooker } \\
\text { et al. } 1912 \\
\text { according to } \\
\text { [28] }\end{array}$ \\
\hline $\begin{array}{l}\text { Rhipicephalus haemaphysaloides } \\
\text { pilans }{ }^{1} \text { partially engorged female } \\
\text { [formerly Rhipicephalus } \\
\text { haemaphysaloides paulopunctatus } \\
\text { Neumann] }\end{array}$ & $\begin{array}{l}\text { Rhipicephalus (Boophilus) } \\
\text { microplus } \text { fully engorged female }_{\text {[formerly Boophilus microplus] }}\end{array}$ & $\begin{array}{l}\text { R. haemaphysaloides: South-Eastern Asia } \\
\text { (Nepal, Burma (Myanmar), India, Taiwan, } \\
\text { Sri Lanka, China, Indonesia, Thailand, } \\
\text { Vietnam) } \\
\text { R. microplus: as mentioned above }\end{array}$ & $\begin{array}{l}\text { R. haemaphysaloides: small mammals } \\
\text { and birds (I); domestic mammals, } \\
\text { e.g. cattle, buffalo, horse, sheep, } \\
\text { camel, donkey, dog, and many wild } \\
\text { mammals (A); } \\
\text { R.microplus: as mentioned above }\end{array}$ & {$[28]$} \\
\hline $\begin{array}{l}\text { Hyalomma detritum }{ }^{2} \text { male } \\
\text { (syn. H. scupense) }\end{array}$ & $\begin{array}{l}\text { Hyalomma detritum }{ }^{2} \text { fully } \\
\text { engorged female } \\
\text { (syn. H. scupense) }\end{array}$ & $\begin{array}{l}\text { Central and Southern Asia, Near East; } \\
\text { Southern Europe; North-Western Africa/ } \\
\text { humid areas in steppes, deserts, and } \\
\text { semi-deserts }\end{array}$ & $\begin{array}{l}\text { Mammals, mainly cattle and other } \\
\text { ungulates }(A, I)\end{array}$ & {$[25]$} \\
\hline $\begin{array}{l}\text { Hyalomma detritum }{ }^{2} \text { (syn. } H \text {. } \\
\text { scupense) unengorged nymph } \\
\text { [formerly Hyalomma } \\
\text { mauritanicum] }\end{array}$ & $\begin{array}{l}\text { Hyalomma detritum }{ }^{2} \text { (syn. } \mathrm{H} \text {. } \\
\text { scupense) } \\
\text { engorged nymph } \\
\text { [formerly Hyalomma } \\
\text { mauritanicum] }\end{array}$ & & & {$[24]$} \\
\hline $\begin{array}{l}\text { Amblyomma fuscolineatum }{ }^{3} \text { two } \\
\text { males } \\
\text { [formerly Aponomma crassipes, } \\
\text { Aponomma fuscolineatum] }\end{array}$ & $\begin{array}{l}\text { Amblyomma fuscolineatum } \\
{ }^{3} \text { engorged female [formerly } \\
\text { Aponomma crassipes, Aponomma } \\
\text { fuscolineatum] }\end{array}$ & $\begin{array}{l}\text { Continens: Australasia } \\
\text { Oceania } \\
\text { Melanesia (Papua New Guinea) } \\
\text { America } \\
\text { North America (USA) }\end{array}$ & Reptiles & $\begin{array}{l}\text { Roubaud } \\
\text { and Colas- } \\
\text { Belcour } 1935 \\
\text { according to } \\
\text { [28] }\end{array}$ \\
\hline $\begin{array}{l}\text { Amblyomma rotundatum }{ }^{2} \\
\text { unergorged female }\end{array}$ & $\begin{array}{l}\text { Amblyomma rotundatum }{ }^{2} \\
\text { partially engorged female }\end{array}$ & $\begin{array}{l}\text { South and Central America (Argentina to } \\
\text { Mexico, including the Caribbean Islands) } \\
\text { and southern part of Florida / savannah, } \\
\text { forest savannah and rainforest habitats }\end{array}$ & Reptiles and amphibians; birds (I, A) & {$[27]$} \\
\hline $\begin{array}{l}\text { Hyalomma excavatum }{ }^{1} \text { partially } \\
\text { engorged female }\end{array}$ & $\begin{array}{l}\text { Hyalomma excavatum }{ }^{1} \text { fully } \\
\text { engorged female }\end{array}$ & $\begin{array}{l}\text { Central and Sout-West Asia; Middle and } \\
\text { Near East; South-Eastern Europe and } \\
\text { southern Africa/warm arid and semi-arid } \\
\text { habitats }\end{array}$ & $\begin{array}{l}\text { Small mammals, mainly rodents that } \\
\text { live in burrows, and birds (I); large } \\
\text { mammals (A) }\end{array}$ & $\begin{array}{l}\text { Buczek et al. } \\
\text { present } \\
\text { study }\end{array}$ \\
\hline \multicolumn{5}{|l|}{ Interspecific hyperparasitism } \\
\hline Ixodes sp. male & $\begin{array}{l}\text { Bothriocroton auruginans female } \\
\text { [formerly Aponomma auruginans } \\
\text { Schulze] }\end{array}$ & $\begin{array}{l}\text { Australia/ I. sp. as mentioned above } \\
\text { B. auruginans: burrows in savanna or } \\
\text { grassland, and forests }\end{array}$ & $\begin{array}{l}\text { B.a. Mammals: e.g. wombats } \\
\text { Ix.sp. }\end{array}$ & [9] \\
\hline Ixodes sp. male & $\begin{array}{l}\text { Rhipicephalus (Boophilus) } \\
\text { microplus female } \\
\text { [formerly Boophilus microplus] }\end{array}$ & R. microplus- as mentioned above & $\begin{array}{l}\text { R. microplus: mammals, mainly } \\
\text { ungulates and carnivores }(A, I)\end{array}$ & [9] \\
\hline
\end{tabular}

' parasitizing on humans; ${ }^{2}$ occasionally parasitizing on humans; ${ }^{3}$ parasitizing on animals (no literature data about feeding on humans exists); (A - adults, I-immatures).

* No literature data exists about feeding on humans.

and interspecific tick contacts have been observed not only in the laboratory but also in nature, prompts consideration of this route of transmission of pathogenic and symbiotic microorganisms among ticks [9].

This current study presents an interesting case of Hyalomma excavatum female parasitism on another conspecific female, and analyses the biological and epidemiological implications of tick hyperparasitism.

The H. excavatum tick is widespread in the Mediterranean region as well as steppe areas of North Africa and South Asia [10]. However, the predicted changes in temperature and precipitation rates will alter the distribution of various species, including $H$. excavatum, which differ in their predilection for habitat conditions [11].

Adult stages infest wild and domestic animals, mainly buffalo, cattle, sheep, goats, camels, horses, and donkeys [12, $13]$, but can also attack humans $[14,15]$. Larvae and nymphs parasitize hares, hedgehogs, and rodents [10].

Since this tick was previously identified as Hyalomma anatolicum and can still be mistaken for this species due to the high morphological similarity, the competence of
H. excavatum to transmit tick-borne pathogens is not known. Theileria buffeli/orientalis, Babesia spp., Anaplasma/Ehrlichia [16], Coxiella burnetii [17, 18], Spotted Fever Group Rickettsiae $[19,20]$, and Crimean-Congo Haemorrhagic Fever Virus (CCHFV) [21] were detected in $H$. excavatum removed from animals. CCHFV is spread in 30 countries and infections with this virus have a fatal outcome in as many as $50 \%$ of cases in humans [22]. Furthermore, Borrelia burgdorferi sensu lato and Rickettsia aeschlimannii were isolated from H. excavatum ticks collected from patients' skin [23].

To the best of the authors' knowledge, to date hyperparasitism has not been described in $H$. excavatum. In the available literature, only two publications were found on hyperparasitic ticks from the genus Hyalomma. Both papers focused on the same species, i.e. a Hyalomma detritum tick foraging on another conspecific specimen. An unengorged Hyalomma mauritanicum nymph (at present $H$. detritum) attached to an engorged nymph was found by Sergent [24] during investigations of the foraging of these ticks on a calf, and a $H$. detritum male attached to an engorged female of this species was observed by Usakov [25]. 


\section{MATERIALS AND METHOD}

H. excavatum rearing was started with specimens kindly donated by colleagues from the Institute of Zoology SAS in Bratislava in 2013. Since these ticks represent a two-host species (only occasionally a three-host species), they were fed on naïve New Zealand rabbits (Oryctolagus cuniculus) twice during their life cycle (adult and larval stages). In one investigation by the authors of the current study, research was undertaken of the biology of H. excavatum, in which larvae hatched from eggs laid by one female were placed on one host.

H. excavatum larvae were placed on $10 \mathrm{~cm}^{2}$ of shaved rabbit skin. After the larvae had moulted into nymphs and the nymphs into adult stages, ticks that had detached from the host skin were collected and transferred to rearing chambers. The chambers were kept at a temperature of $25^{\circ} \mathrm{C}$ and $75 \%$ humidity, maintained with the method proposed by Winston and Bates [26]. One chamber contained approximately 8 adult specimens, including $3 \mathrm{H}$. excavatum females with a varied degree of engorgement and 5 males.

All procedures performed on the animals were approved by the Local Ethics Committee (No. 22/2015).

\section{RESULTS AND DISCUSSION}

In one of the rearing chambers, there were 2 partially engorged females, one fully engorged female, and 5 males among the $H$. excavatum adult specimens collected from the naive host. The 2 partially engorged females attempted to replenish the amounts of food ingested during the infestation of the rabbit. Approximately 3 and 4 days after detachment from the host's skin, they attached to the posterior dorsal part of the idiosoma of a fully engorged conspecific female. One of the partially engorged females detached after several hours, whereas the other one remained with its hypostome inserted into the body of the fully engorged female (Fig. 1). As can be seen, the long mouthparts of the partially engorged $H$. excavatum female penetrated deep inside the body of the fully engorged specimen. Its entire hypostome was attached to the idiosoma of the other female. It probably reached the intestine with its multiple blood-filled caeca and the haemocel cavity of the fully engorged specimen. Disruption of the continuity of their walls caused an outflow of the intestinal contents and haemolymph. This is indicated by the darker colouration of the idiosoma of the fully engorged specimen at the site of attachment of the conspecific female. A similar sign was visible on the idiosoma after the feeding of the other partially engorged female.

Hyperparasitism in ticks has been poorly explored. Hungry ticks attached to engorged specimens were usually found accidentally among ticks collected from animals or in laboratory rearing conditions. Therefore, it is not known how often and in which conditions ticks become hyperparasitic in nature. The few papers available provide exact numbers of ticks among which hyperparasitic specimens were found. In a group of 82 Amblyomma rotundatum ticks ( 81 females and one nymph) removed from snakes, Labruna et al. [27] found one unengorged female attached to a partially engorged female already 15 minutes after removal from the host.

Tick hyperparasitism may not be as rare in nature as suggested by data provided by some authors [24, 28]. This is indicated by multiple traces of tick bites (scars) that were

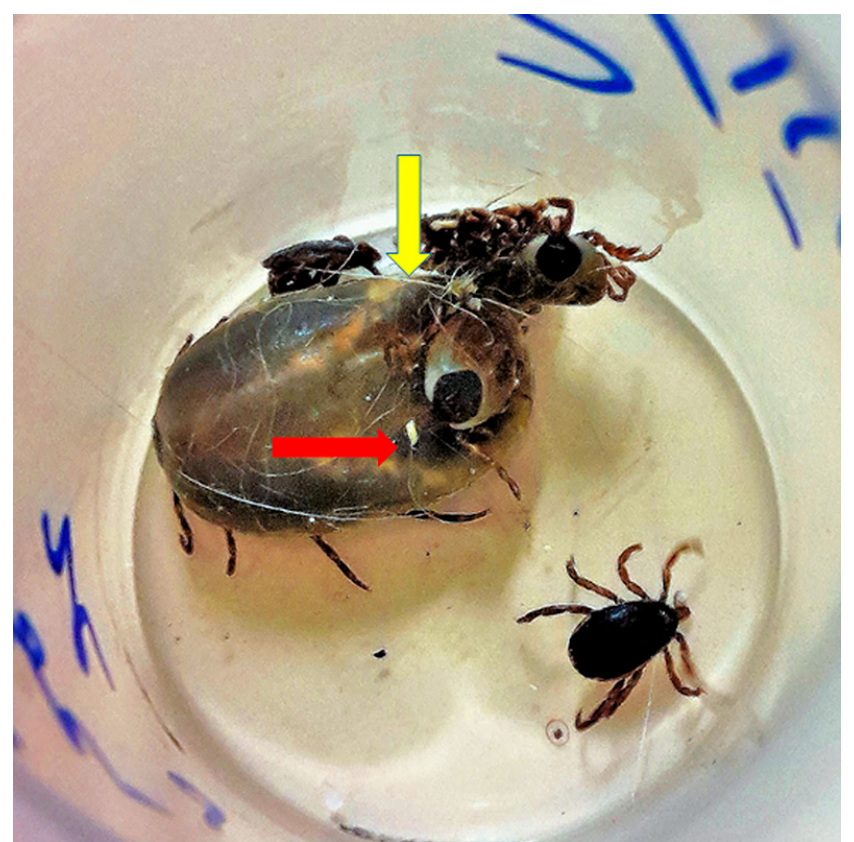

Figure 1. Hyalomma excavatum partially engorged female attached to the posterior dorsal part of the idiosoma of a fully engorged conspecific female (red arrow); trace of tick bite-scar (yellow arrow)

found on the idiosoma of engorged specimens representing prostriata ticks $[9,29-33]$, and metastriata ticks [27] that were close to other hungry or partially engorged conspecific specimens. In ther opinion of the authors of the current study, the dark-coloured permanent scars on the tick idiosoma and some exoskeletal anomalies in specimens collected in nature [34-37] may have been caused by other ticks that parasitized these specimens, or their earlier stages, i.e. nymphs (own observations, unpublished data).

As many as $27.8 \%$ of 162 Ixodes trianguliceps females examined were found to have been attacked by conspecific males. The number of scars on the female bodies increased with the higher degree of engorgement. Scars were noted in $41 \%$ of partially fed females. The female genital opening was the most common site of attachment of males [31].

One specimen can be parasitized by several other individuals. In Ixodes (Afrixodes) moreli females, 1 - 9 scars were noted. One female of this species was simultaneously parasitized by up to 5 males. Approximately $32.4 \%$ of $I$. (A.) moreli males attached to females [32], which may indicate a high frequency of this phenomenon.

Scars left by male tick bites on the bodies of Ixodes persulcatus females collected in nature were observed more frequently during hotter seasons than during seasons with moderate temperatures [33].

In certain circumstances, hyperparasitism can be the only way to obtain food by hungry tick specimens. In natural conditions, questing for a host by some species may be difficult, as they react to stimuli emitted by the host when present at a short distance from the source, e.g. Argas reflexus responds at a distance of a few $\mathrm{cm}$ from the host [38]. Moreover, non-nidicolous ticks with an ambush host-seeking life strategy, e.g. Dermacentor reticulatus, Ixodes scapularis, or Ixodes ricinus, cover short distances.

Over 7 weeks, D. reticulatus females and males at an average temperature of $18.3^{\circ} \mathrm{C}$ and $56.7 \%$ humidity in the habitat, moved horizontally over a distance of only $66.35 \pm 100 \mathrm{~cm}$ 
and $54.85 \pm 45 \mathrm{~cm}$, respectively [39]. I. scapularis adult stages cover a distance of $5-6$ m over 3 - 4 weeks [40], and I. ricinus females and males move for a distance of ca. $4.75 \mathrm{~m}$ and $1 \mathrm{~m}$, respectively, over 3 weeks [41].

A completely different situation occurs in Hyalomma asiaticum. It is reported that in this species $10 \%-25 \%$ of marked ticks, one month after discharge were registered at a distance of $100-400 \mathrm{~m}$; several individuals even more than $500 \mathrm{~m}$. This is explained by the fact that while most tick species of genera Ixodes and Rhipicephalus passively wait for the host, $H$. asiaticum ticks actively search the host [42].

Hungry ticks usually attack partially or fully engorged specimens from the same species, but can also parasitize interspecific ticks (Tab. 1). In the current study, a partially engorged $H$. excavatum female was noted attached to a fully engorged female. This particularly interesting case shows that partially engorged ticks can repeatedly feed on fully engorged specimens. They can also quest for a new host, e.g. an animal or even a human, to replenish the amounts of food that will ensure maintenance of all vital functions and, possibly, their further development. A case of attachment of a partially engorged $I$. ricinus female to the forearm of a man has been noted. The tick detached from the skin of a cat (Felis catus) wearing an anti-tick collar. The tick fed on the patient for ca. 10 hours and infected him with Borrelia burgdorferi s.l. spirochetes, which was manifested by the development of erythema migrans (unpublished data). In the current study, partially engorged nymphs of I. ricinus were sampled several times by flagging methods (unpublished data). This means, that ticks need to take some critical portion of blood before metamorphosis (unpublished data).

Earlier, Anastos [28] described a partially engorged Rhipicephalus haemaphysaloides paulopunctatus female attached to a fully engorged male from a different species, i.e. Rhipicephalus (Boophilus) microplus. The specimens were found among several thousand ticks collected from domestic animals in the Dutch East Indies (today Indonesia).

Hard ticks usually attach to their host and detach only after ingestion of the maximum portion of a blood meal. The body weight of fully engorged specimens is several-fold higher than that of hungry ticks; it increases 190-fold in $I$. ricinus females, and 88-fold in D. reticulatus females [43]. Detachment of partially engorged $H$. excavatum females from the host may be caused by a high concentration of ticks, which triggers a strong local reaction in rabbit skin to the components of tick saliva introduced during feeding and changes in the quality of ingested blood meal.

The greater the intensity of tick invasion, the greater the changes in the parasitic phase parameters, such as the length of time and effectiveness of the feeding [43]. The weight of engorged females can be influenced by other factors, e.g. nutritional status of the host, host immunisation acquired in previous tick infestations, other species co-feeding on the same host [44-46], and some chemicals used for tick control in animals [47]. In natural conditions, the detachment of hungry and partially engorged ticks can be caused by the death of the host [48]. The amount of blood ingested by a female determines the number of oviposited eggs and, consequently, the number of offspring.

Different tick developmental stages, such as adult stages (males and females) and nymphs, can be hyperparasites (Tab. 1). Attachment of a hungry or partially engorged tick to an engorged specimen may be a desperate way of obtaining food in the absence of a target host, or a way of replenishment of food reserves by specimens detached from host skin before ingestion of a full portion of blood. Feeding, which involves alternate insertion of saliva and sucking host blood portions, promotes transmission of microorganisms from an infected to non-infected specimen, or even an exchange of pathogens between two infected ticks. During host blood ingestion, microorganisms present in the infected tick multiply intensively and spread with the haemolymph around the organism [49]. In a systemic infection, pathogens are present in many tick organs which can be penetrated by the mouthparts of another specimen. The long mouthparts of species from the genera Ixodes, Aponomma, Amblyomma, and Hyalomma are able to reach deep into the tick's body. Similarly, for example, Řeháček [50] wrote that during the generalized form of tick infection, rickettsiae were registered in haemolymph, intestine, salivary glands, Malpighi glands, ovaries, or testes of ticks, i.e. in the whole body of the tick.

Conspecific hyperparasitism may contribute to the spread of pathogens within a tick population in natural conditions. This is suggested by the results of previous laboratory investigations confirming transmission of Dipetalonema viteae in Ornithodorus tartakovskyi [51], Borrelia crocidurae in Ornithodoros erraticus [52], and Borrelia burgdoreri s.l. spirochetes in Ixodes persulcatus [33]. Furthermore, symbiotic bacteria or fungi whose biological role is not fully known can be transmitted during physical contact between ticks [53-55]. Many symbiotic microorganisms that turned out to be human and animal pathogens have been identified in ticks [56]. It seems that tick hyperparasitism can contribute to the high genospecific diversity of some pathogens, for instance Borrelia burgdorferi s.l. [57] or Crimean-Congo haemorrhagic fever virus [58], as well as multiple pathogen coinfections in ticks [59-64] and in hosts [65-67].

The current study indicates that partially engorged ixodid ticks can re-infect a host in order to accumulate an amount of food indispensable for their survival and further development. Hyperparasitism may be a yet poorly known route of microbial transmission in ticks, which may contribute to the spread and maintenance of pathogens in nature. It is probably responsible for the occurrence of genospecific diversity of pathogens in ticks and their hosts. Future investigations of the epidemiology of tick-borne diseases in humans and animals should consider this route of pathogen transmission and explain its role in natural conditions.

\section{REFERENCES}

1. de la Fuente J, Estrada-Peña A, Venzal JM, Kocan KM, Sonenshine DE. Overview: Ticks as vectors of pathogens that cause disease in humans and animals. Front Biosci. 2008; 13: 6938-6946.

2. Jongejan F, Uilenberg G. The global importance of ticks. Parasitology. 2004; 129: S3-14.

3. Dantas-Torres F, Chomel BB, Otranto D. Ticks and tick-borne diseases: a One Health perspective. Trends Parasitol. 2012; 28(10): 437-446.

4. Ghosh S, Nagar G. Problem of ticks and tick-borne diseases in India with special emphasis on progress in tick control research: A review. J Vector Borne Dis. 2014; 51: 259-270.

5. Kemp D, Stone B, Binnington K. Tick attachment and feeding: Role of the mouthparts, feeding apparatus, salivary gland secretions and the host response. In: Obenchain F, Galun R, editors, Physiology of Ticks. Pergamon Press, Oxford; 1982. p. 119-168.

6. Šimo L, Kazmirova M, Richardson J, Bonnet SI. The essential role of tick salivary glands and saliva in tick feeding and pathogen transmission. Front Cell Infect Microbiol. 2017; 7: 281. 
7. Barber CA. The tick pest in the tropics. Nature. 1895; 52: 197-200.

8. Londoňo IM. Transmission of microfilariae and infective larvae of Dipetalonema viteae (Filarioidea) among vector ticks, Ornithodoros tartakowskyi (Argasidae), and loss of microfilariae in coxal fluid. J Parasitol. 1976; 62(5): 786-788.

9. Moorhouse DE, Heath AC. Parasitism of female ticks by males of the genus Ixodes. J Med Entomol. 1975; 12: 571-572.

10. Camicas JL, Hervy JP, Adam F, Morel PC. The ticks of the world: nomenclature, described stages, hosts, distribution (Acaridida, Ixodida). Orstom, Paris, 1998.

11. Estrada-Peña A, Venzal JM. Climate niches of tick species in the Mediterranean region: modeling of occurrence data, distributional constraints, and impact of climate change. J Med Entomol. 2007; 44(6): 1130-1138.

12. Riabi HRA, Atarodi A. Faunistic study of hard ticks (Ixodidae) of domestic ruminants in the Southern Khorasan-e-Razavi in comparing with other regions of the Province in 2012 Iran. J Vet Adv. 2014; 4(5): 508-515.

13. Chhillar S, Chhilar JS, Kaur H. Investigations on some hard ticks (Acari: Ixodidae) infesting domestic buffalo and cattle from Haryana, India. J Entomol Zool Stud. 2014; 2(4): 99-104.

14. Kar S, Dervis E, Akın A, Ergonul O, Gargili A. Preferences of different tick species for human hosts in Turkey. Exp Appl Acarol. 2013; 61(3): 349-355.

15. Keskin A, Bulut YE, Keskin A, Bursali A. Tick attachment sites in humans living in the Tokat province of Turkey. Turk Hij Den Biyol Derg. 2017; 74: 121-128.

16. Aktas M, Altay K, Ozubek S, Dumanli N. A survey of ixodid ticks feeding on cattle and prevalence of tick-borne pathogens in the Black Sea region of Turkey. Vet Parasitol. 2012; 187(3-4): 567-571.

17. Psaroulaki A, Ragiadakou D, Kouris G, Papadopoulos B, Chaniotis B, Tselentis Y. Ticks, tick-borne rickettsiae, and Coxiella burnetii in the Greek Island of Cephalonia. Ann N Y Acad Sci. 2006; 1078: 389-399.

18. Ghashghaei O, Nourollahi-Fard SR, Khalili M, Sharifi H. A survey of ixodid ticks feeding on cattle and molecular detection of Coxiella burnetii from ticks in Southeast Iran. Turk J Vet Anim Sci. 2017; 41(1): 46-50.

19. Chochlakis D, Ioannou I, Sandalakis V, Dimitriou T, Kassinis N, Papadopoulos B, Tselentis Y, Psaroulaki A. Spotted Fever Group Rickettsiae in Ticks in Cyprus. Microb Ecol. 2012; 63(2): 314-323.

20. Leulmi H, Aouadi A, Bitam I, Bessas A, Benakhla A, Raoult D, Parola P. Detection of Bartonella tamiae, Coxiella burnetii and rickettsiae in arthropods and tissues from wild and domestic animals in northeastern Algeria. Parasit Vectors. 2016; 9: 27.

21. Akuffo R, Brandful JAM, Zayed A, Adjei A, Watany N, Fahmy NT, Hughes R, Doman B, Voegborlo SV, Aziati D, Pratt D, Awuni JA, Adams N, Dueger E. Crimean-Congo hemorrhagic fever virus in livestock ticks and animal handler seroprevalence at an abattoir in Ghana. BMC Infect Dis. 2016; 16: 324

22. Zavitsanou A, Babatsikou F, Koutis C. Crimean Congo hemorrhagic fever: an emerging tick-borne disease. Health Sci J. 2009; 3(1): 10-18.

23. Orkun Ö, Karaer Z, Çakmak A, Nalbantoğlu S. Identification of TickBorne Pathogens in Ticks Feeding on Humans in Turkey. PLoS Negl Trop Dis. 2014; 8: e3067.

24. Sergent A. Presentation d'une nymphe de tique parasitant une autre nymphe de la me^me espe`ce. Bull Soc Hist Nat Afr N. 1930; 21: 195 (in French).

25. Usakov UY. Homoparasitism in the Ixodic ticks. Zool Zh. 1961; 40: 608 (in Russian).

26. Winston PW, Bates DH. Saturated Solutions for the Control of Humidity in Biological Research. Ecology. 1960; 41: 232-237.

27. Labruna MB, Ahid SMM, Soares HS, Suassuna ACD. Hyperparasitism in Amblyomma rotundatum (Acari: Ixodidae). J Parasitol. 2007; 93: 1531-1532.

28. Anastos G. Accidental Parasitism of a tick by a tick. Psyche. 1948; 55: 36-37.

29. Moorhouse DE. Observations on copulation in Ixodes holocyclus Neumann and the feeding of the male. J Med Entomol. 1966; 3(2): 168-171.

30. Norval RAI. Copulation and feeding in males of Ixodes pilosus Koch 1844 (Acarina: Ixodidae). J Ent Soc Sth Africa. 1974; 37: 129-133.

31. Nilsson A. Parasitism of female Ixodes trianguliceps by the males. Oikos. 1975; 26: 295-298.

32. Ntiamoa-Baidu Y. Parasitism of female Ixodes (Afrixodes) moreli (Acari: Ixodidae) by males. J Med Entomol. 1986; 23(5): 484-488.

33. Alekseev AN, Dubinina HV. Exchange of Borrelia burgdorferi between Ixodes persulcatus (Ixodidae: Acarina) sexual partners. J Med Entomol. 1996; 33(3): 351-354.
34. Alekseev AN, Dubinina HV. Some aspects of mite (Oppiidae) and tick (Ixodidae) pathology as a result of anthropogenic pressure. In: Mitchell R, HornDJ, Needham GR and Welbourn WC, editors, Acarology IX. vol. 1. Ohio Biological Survey, Columbus; 1996. p. 117-20.

35. Alekseev AN, Dubinina HV. Enhancement of risk of tick-borne infection: environmental and parasitological aspects of the problem. J Med Entomol. 2008; 45(4): 812-815.

36. Žygutienè M, Alekseev A, Dubinina H, Kazlauskienè R. Evidence for a risk of tick-borne infection in the city parks of Vilnius, Lithuania. Ekologija. 2008; 54(1): 40-43.

37. Nikitin AY, Morozov IM. Exoskeleton anomalies among taiga tick males from populations of the Asiatic part of Russia. Parazitologiia, 2017; 51: 38-44 (in Russian).

38. Boxler B, Odermat P, Haag-Wackernagel D. Host finding of the pigeon tick Argas reflexus. Med Vet Entomol. 2016; 30(2): 193-199.

39. Buczek A, Zając Z, Woźniak A, Kulina D, Bartosik K. Locomotor activity of adult Dermacentor reticulatus ticks (Ixodida: Ixodidae) in natural conditions. Ann Agric Environ Med. 2017; 24(2): 271-275.

40. Carroll JF, Schmidtmann ET. Dispersal of blacklegged tick (Acari: Ixodidae) nymphs and adults at the woods-pasture interface. J Med Entomol. 1996; 33: 554-558.

41. Černý V. Horizontal migration at the tick (Ixodes ricinus L.). Folia Zool. 1959; 8: 208-212.

42. Černý V. How fast the ticks move. Živa. 1961; 9: 68 (in Czech).

43. Bartosik K, Buczek A. The impact of intensity of invasion of Ixodes ricinus and Dermacentor reticulatus on the course of the parasitic phase. Ann Agric Environ Med. 2012; 19(4): 651-655.

44. Buczek A, Bartosik K, Zając Z, Stanko M. Host-feeding behaviour of Dermacentor reticulatus and Dermacentor marginatus in mono-specific and inter-specific infestations. Parasit Vectors. 2015; 8: 470.

45. Rechav Y, Hay L. The effects of nutritional status of rabbits and sheep on their resistance to the ticks Rhipicephalus evertsi evertsi and $R$. appendiculatus. Exp Appl Acarol. 1992; 15(3): 171-179.

46. Heinze DM, Carmical JR, Aronson JF, Alarcon-Chaidez F, Wikel S, Thangamani S. Murine cutaneous responses to the rocky mountain spotted fever vector, Dermacentor andersoni, feeding. Front Microbiol. 2014; 5: 198.

47. Buczek A, Lachowska-Kotowska P, Bartosik K. The effect of synthetic pyrethroids on the attachment and host-feeding behaviour in Dermacentor reticulatus females (Ixodida: Amblyommidae). Parasit Vectors. 2015; 8: 366.

48. Tsunoda T. Detachment of hard ticks (Acari: Ixodidae) from hunted sika deer (Cervus nippon). Exp Appl Acarol. 2014; 63(4): 545-550.

49. Sonenshine DE, Roe RM. Biology of Ticks 2nd Edition. Vol. 1 Oxford University Press, New York, 2014.

50. Řeháček J. Rickettsia slovaca - the organism and its ecology. Academia, Prague, 1984.

51. Votava CL, Rabalais FC, Ashley DC. Transmission of Dipetalonema viteae by hyperparasitism in Ornithodorus tartakovskyi. J Parasitol. 1974; 60: 479.

52. Helmy N, Khalil GM, Hoogstraal H. Hyperparasitism in Ornithodoros erraticus. J Parasitol. 1983; 69(1): 229-233.

53. Samsinakova A, Kalalova S, Daniel M, Dusbabek F, Honzakova E, Černý V. Entomogenous fungi associated with the tick Ixodes ricinus (L.). Folia Parasitol. 1974; 21(1): 39-48.

54. Yoder JA, Hanson PE, Zettler LW, Benoit JB, Ghisays F, Piskin K. Internal and external mycoflora of the American dog tick, Dermacentor variabilis (Acari: Ixodidae), and its ecological implications. Appl Environ Microbiol. 2003; 69(8): 4994-4996.

55. Greengarten PJ, Tuininga AR, Morath SU, Falco RC, Norelus H, Daniels TJ. Occurrence of soil- and tick-borne fungi and related virulence tests for pathogenicity to Ixodes scapularis (Acari: Ixodidae). J Med Entomol. 2011; 48(2): 337-344.

56. Noda H, Munderloh UG, Kurtti TJ. Endosymbionts of ticks and their relationship to Wolbachia spp. and tick-borne pathogens of humans and animals. Appl Environ Microbiol. 1997; 63(10): 3926-3932.

57. Crowder CD, Matthews HE, Schutzer S, Rounds MA, Luft BJ, Nolte O, Campbell SR, Phillipson CA, Li F, Sampath R, Ecker DJ, Eshoo MW. Genotypic variation and mixtures of Lyme Borrelia in Ixodes ticks from North America and Europe. PLoS One. 2010; 5: e10650.

58. Yashina L, Petrova I, Seregin S, Vyshemirskii O, Lvov D, Aristova V, Kuhn J, Morzunov S, Gutorov V, Kuzina I, Tyunnikov G, Netesov S, Petrov V. Genetic variability of Crimean-Congo haemorrhagic fever virus in Russia and Central Asia. J Gen Virol. 2003; 84: 1199-1206.

59. Alekseev AN, Semenov AV, Dubinina HV. Evidence of Babesia microti infection in multi-infected Ixodes persulcatus ticks in Russia. Exp Appl Acarol. 2003; 29(3-4): 345-353. 
60. Stańczak J, Gabre RM, Kruminis-Łozowska W, Racewicz M, KubicaBiernat B. Ixodes ricinus as a vector of Borrelia burgdorferi sensu lato, Anaplasma phagocytophilum and Babesia microti in urban and suburban forests. Ann Agric Environ Med. 2004; 11(1): 109-114.

61. Otranto D, Dantas-Torres F, Giannelli A, Latrofa M.S, Cascio A, Cazzin S, Ravagnan S, Montarsi F, Zanzani SA, Manfredi MT, Capelli G. Ticks infesting humans in Italy and associated pathogens. Parasit Vectors. 2014; 7: 328 .

62. Asman M, Nowak-Chmura M, Solarz K, Szilman E, Semla M, Zyśk B. Anaplasma phagocytophilum, Babesia microti, Borrelia burgdorferi sensu lato, and Toxoplasma gondii in Ixodes ricinus (Acari, Ixodida) ticks collected from Slowinski National Park (Northern Poland). J Vector Ecol. 2017; 42(1): 200-202.

63. Raileanu C, Moutailler S, Pavel I, Porea D, Mihalca AD, Savuta G, Vayssier-Taussat M. Borrelia diversity and co-infection with other tick borne pathogens in ticks. Front Cell Infect Microbiol. 2017; 7: 36.

64. Zając V, Wójcik-Fatla A, Sawczyn A, Cisak E, Sroka J, Kloc A, Zając Z, Buczek A, Dutkiewicz J, Bartosik K. Prevalence of infections and coinfections with 6 pathogens in Dermacentor reticulatus ticks collected in eastern Poland. Ann Agric Environ Med. 2017; 24(1): 26-32.

65. Moniuszko A, Dunaj J, Święcicka I, Zambrowski G, ChmielewskaBadora J, Żukiewicz-Sobczak W, Zajkowska J, Czupryna P, Kondrusik M, Grygorczuk S, Swierzbinska R, Pancewicz S. Co-infections with Borrelia species, Anaplasma phagocytophilum and Babesia spp. in patients with tick-borne encephalitis. Eur J Clin Microbiol Infect Dis. 2014; 33(10): 1835-1841.
66. Jahfari S, Hofhuis A, Fonville M, van der Giessen J, van Pelt W, Sprong H. Molecular Detection of Tick-Borne Pathogens in Humans with Tick Bites and Erythema Migrans, in the Netherlands. PLoS Negl Trop Dis. 2016; 10(10): e0005042.

67. Vascellari M, Ravagnan S, Carminato A, Cazzin S, Carli E, Da Rold G, Lucchese L, Natale A, Otranto D, Capelli G. Exposure to vector-borne pathogens in candidate blood donor and free-roaming dogs of northeast Italy. Parasit Vectors. 2016; 9: 369.

68. Beck AF, Holscher KH, Butler JF. Life cycle of Ornithodoros turicata americanus (Acari: Argasidae) in the laboratory. J Med Entomol. 1986; 23(3): 313-319.

69. Davis GE. Ornithodoros parkeri Cooley: Observations on the Biology of This Tick. J Parasitol. 1941; 27(5): 425-433.

70. Endris RG, Haslett TM, Monahan MJ, Phillips JG. Laboratory biology of Ornithodoros (Alectorobius) puertoricensis (Acari: Argasidae). J Med Entomol. 1991; 28(1): 49-62.

71. Oliver JH Jr, McKeever S, Pound JM. Parasitism of larval Ixodes ticks by chigger mites and fed female Ornithodoros ticks by Ornithodoros males. J Parasitol. 1986; 72(5): 811-812.

72. Alekseev AN, Dubinina HV. Venereal and cannibalistic ways of Borrelia burgdorferi sensu lato exchange between males and females of Ixodes persulcatus. Rocz Akad Med Bialymst. 1996; 41: 103-110.

73. Durden LA, Gerlach RF, Beckmen KB, Greiman SE. Hyperparasitism and non-nidicolous mating by male Ixodes angustus ticks (Acari: Ixodidae). J Med Entomol. 2018; 55(3): 766-768.

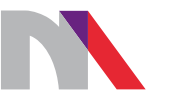

\section{Ministry of Science and Higher Education}

Republic of Poland

Generation of the DOI (Digital Object Identifier) - task financed under the agreement No. 618/P-DUN/2019 by the Minister of Science and Higher Education 